\title{
Determination of optimum retrograde cerebral perfusion conditions
}

Retrograde cerebral perfusion through a superior vena caval cannula is a new technique used to protect the brain during operations on the aortic arch. We measured cerebral tissue blood flow, oxygen consumption, and cerebrospinal fluid pressure under various perfusion conditions in hypothermic $\left(20^{\circ}\right.$ C) mongrel dogs $(n=18,12.8 \pm 0.6 \mathrm{~kg})$ to determine the optimum conditions for retrograde cerebral perfusion. Retrograde cerebral perfusion was performed by infusion via the superior vena caval cannula and drainage via the ascending aortic cannula while the inferior vena cava and azygos vein were clamped. Retrograde cerebral perfusion was performed as the external jugular venous pressure was changed from 15 to $35 \mathrm{~mm} \mathrm{Hg}$ in increments of $5 \mathrm{~mm} \mathrm{Hg}$. Cerebral tissue blood flow was measured by the hydrogen clearance method. Hypothermic retrograde cerebral perfusion with an external jugular venous pressure of $25 \mathrm{~mm} \mathrm{Hg}$ provided about half the cerebral tissue blood flow of hypothermic $\left(20^{\circ}\right.$ C) cardiopulmonary bypass with a flow rate of $1000 \mathrm{ml} / \mathrm{min}(13.7 \pm 7.9$ versus $32.7 \pm 8.5 \mathrm{ml} / \mathrm{min}$ per $100 \mathrm{gm}$ ). It decreased significantly as the external jugular venous pressure was decreased from 25 to $15 \mathrm{~mm} \mathrm{Hg}$ but did not increase significantly as the external jugular venous pressure was increased from 25 to $35 \mathrm{~mm} \mathrm{Hg}$. Whole-body oxygen consumption during hypothermic retrograde cerebral perfusion with an external jugular venous pressure of $25 \mathrm{~mm} \mathrm{Hg}$ was one quarter of that during hypothermic cardiopulmonary bypass $(3.4 \pm 0.7$ versus $12.7 \pm 5.6 \mathrm{ml} / \mathrm{min})$ and varied in proportion to external jugular venous pressure. The cerebrospinal fluid pressure was a little lower than the external jugular venous pressure $(19.2 \pm 4.5 \mathrm{~mm} \mathrm{Hg}$ versus $24.8 \pm 2.4 \mathrm{~mm} \mathrm{Hg})$ but also varied with the external jugular venous pressure. The cerebrospinal fluid pressure remained lower than $25 \mathrm{~mm} \mathrm{Hg}$ so long as the external jugular venous pressure remained lower than $25 \mathrm{~mm} \mathrm{Hg}$. High external jugular venous pressure was associated with high intracranial pressure, which restricts cerebral tissue blood flow and may cause brain edema. We believe that a venous pressure of $25 \mathrm{~mm} \mathrm{Hg}$ is the optimum condition for retrograde cerebral perfusion. (J THORAC CARDIOVASC SuRg 1994;107:300-8)

Akihiko Usui, MD, ${ }^{\mathrm{a}}$ Keiji Oohara, MD, ${ }^{\mathrm{a}}$ Tong-lin Liu, MD, ${ }^{\mathrm{a}}$ Mitsuya Murase, MD, ${ }^{\mathrm{b}}$

Minoru Tanaka, MD, ${ }^{\mathrm{a}}$ Eiji Takeuchi, MD, ${ }^{\mathrm{a}}$ and Toshio Abe, MD, ${ }^{\mathrm{a}}$ Nagoya and Gifu, Japan

$\mathrm{R}$ etrograde cerebral perfusion through a superior vena caval (SVC) cannula is a new and simple technique for

From Nagoya University School of Medicine, Department of Thoracic Surgery, Nagoya, Aichi, Japan, ${ }^{\text {a }}$ and Oogaki Municipal Hospital, Thoracic Surgery Division, Oogaki, Gifu, Japan. ${ }^{\text {b }}$

Supported by a Grant-in-Aid for Scientific Research and a Japan Heart Foundation Research Grant for 1990.

Received for publication Aug. 27, 1992.

Accepted for publication May 17, 1993.

Address for reprints: Akihiko Usui, MD, 2-903 Umegaoka, Tenpakuku, Nagoya, Japan 468.

Copyright 1994 by Mosby-Year Book, Inc.

$0022-5223 / 94 \$ 1.00+.10 \quad \mathbf{1 2} / \mathbf{1} / \mathbf{4 9 7 9 2}$ protecting the cerebrum during operations on the aortic arch. Retrograde cerebral perfusion can provide the blood flow and oxygen to brain tissue. ${ }^{1}$ Although it should reduce ischemic damage to the brain, retrograde cerebral perfusion may be associated with high pressure in the SVC system and may cause brain edema which, in turn, would cause brain damage. Optimum conditions for retrograde cerebral perfusion must be determined to minimize the disadvantages of this perfusion technique. We report our measurements of cerebral tissue blood flow (CBF), oxygen consumption, and cerebrospinal fluid (CSF) pressure under various perfusion conditions in mongrel dogs to determine the optimum conditions for retrograde cerebral perfusion. 
The Journal of Thoracic and

Cardiovascular Surgery

Volume 107, Number 1

\section{Methods}

All animals received humane care in compliance with the "Principles of Laboratory Animal Care" formulated by the National Society for Medical Research and the "Guide for the Care and Use of Laboratory Animals" prepared by the National Society for Medical Research and the "Guide for the Care and Use of Laboratory Animals" prepared by the Institute of Laboratory Animal Resources and published by the National Institutes of Health (NIH Publication No. 86-23, revised 1985).

Preparation of animals and methods of retrograde cerebral perfusion. Eighteen mongrel dogs with a mean weight of $12.8 \pm 0.6(12$ to $14 \mathrm{~kg}$ ) were used for this study. Anesthesia was induced with ketamine hydrochloride, $10 \mathrm{mg} / \mathrm{kg}$, given intramuscularly and thiopental sodium, $5 \mathrm{mg} / \mathrm{kg}$, given intravenously. After endotracheal intubation, the animal was ventilated mechanically with $100 \%$ oxygen. The ventilatory rate and tidal volume were adjusted to maintain the arterial carbon dioxide tension around $35 \mathrm{~mm} \mathrm{Hg}$. Anesthesia was maintained with intravenous ketamine hydrochloride, $2 \mathrm{mg} / \mathrm{kg}$ per hour.

Catheters were placed in the right external jugular vein, right femoral vein, and brachiocephalic artery to measure blood pressures. CBF was measured by the hydrogen clearance method. A hydrogen electrode was inserted into the mid-central parietal lobe cortex through a burr hole in the skull. A perfusion cannula $(8 \mathrm{~F})$ for retrograde cerebral perfusion was placed in both internal maxillary veins. A catheter was also placed in the subarachnoid cavity through the occipitocervical space to measure the CSF pressure.

A thoracotomy incision was made through the right fourth intercostal space. Heparin, $300 \mathrm{U} / \mathrm{kg}$, was given intravenously. The ascending aorta was cannulated with a $16 \mathrm{~F}$ metal-tipped perfusion catheter. The right atrium was cannulated with two separate venous cannulas ( $28 \mathrm{~F}$ ), vena caval tapes were applied, and the azygos vein was clamped. Cardiopulmonary bypass (CPB) was established at a flow rate of $1000 \mathrm{ml} / \mathrm{min}$ with administration of pure oxygen at $0.5 \mathrm{~L} / \mathrm{min}$. Mechanical ventilation was discontinued, a crossclamp was applied to the ascending aorta, the heart was arrested, and intermittent cold crystalloid cardioplegic solution was applied. Core cooling was used to maintain the difference in inflow and outflow blood temperature within $5^{\circ} \mathrm{C}$. The nasopharyngeal core temperature was reduced to $20^{\circ} \mathrm{C}$ with an average cooling time of $17.5 \pm 1.2$ minutes and was maintained around $20^{\circ} \mathrm{C}$ with intermittent cooling of infused solution, whose temperature was around $18^{\circ} \mathrm{C}$ (control $\mathrm{CPB}$ ). Then retrograde cerebral perfusion was established by perfusion of blood through cannulas in both internal maxillary veins with separate pumps to maintain a nasopharyngeal core temperature around $20^{\circ} \mathrm{C}$ with intermittent cooling of inflow blood. The aortic cannula was opened and directed by gravity to the cardiotomy reservoir while both caval cannulas were clamped (Fig. 1). The pump circuit consisted of a Capiox $0.8 \mathrm{~m}^{2}$ oxygenator with a cardiotomy reservoir (BPC-350, Aika Medical Corp., Matsudo City, Japan) primed with electrolyte solution and $500 \mathrm{ml}$ of blood obtained from another dog. No intervention was made to control blood pressure during this study.

Experimental protocol. CPB was begun at a flow rate of $1000 \mathrm{ml} / \mathrm{min}$. The animal was cooled to a nasopharyngeal temperature of $20^{\circ} \mathrm{C}$ and its temperature was maintained around $20^{\circ} \mathrm{C}$ with intermittent cooling of inflow blood (control CPB). Then perfusion was switched to retrograde cerebral perfusion

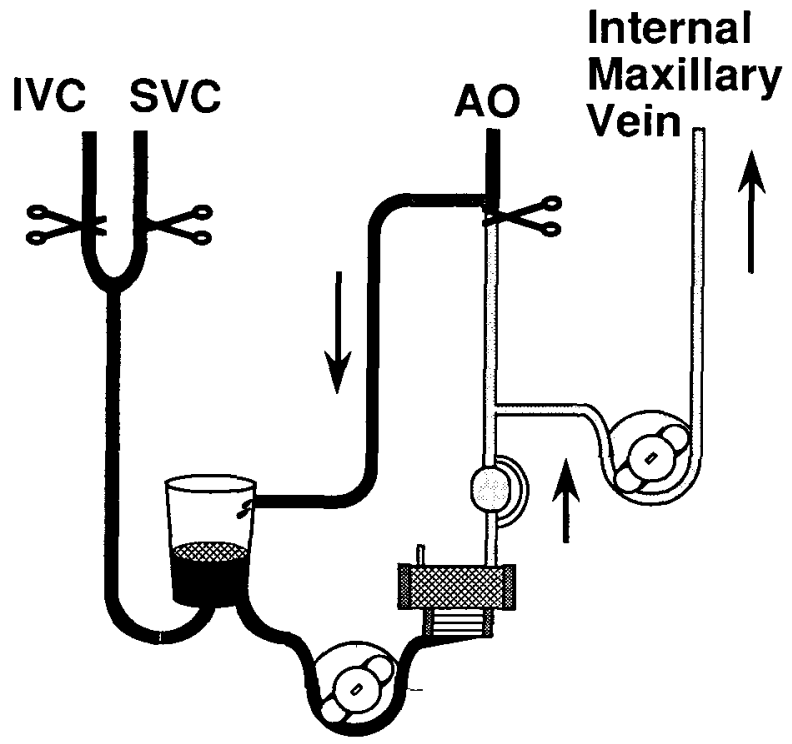

Fig. 1. Perfusion and drainage in retrograde cerebral perfusion through an SVC cannula. Only the aortic cannula $(A O)$ was opened and directed by gravity to the cardiotomy reservoir while the caval cannulas were clamped. Returned blood (dark gray) was perfused through an oxygenator into both the internal maxillary venous cannulas with a separate pump (light gray).

while the external jugular venous pressure was monitored. During retrograde cerebral perfusion, external jugular venous pressure was varied from 15 to $20,25,30$, and $35 \mathrm{~mm} \mathrm{Hg}$ consecutively at 10 -minute intervals. During each interval, external jugular venous pressure was maintained to be a certain pressure with varying perfusion flow rates. At the end of each period, the blood pressure in each catheter was recorded and blood was sampled from the inflow and outflow cannulas. Flow rate of blood returning from the aorta was measured directly. The CSF pressure and $\mathrm{CBF}$ were measured simultaneously. After each procedure the skull was opened and blood perfusion via each internal maxillary vein was observed directly to detect the interruption by venous valves.

Analysis. Blood pressure and CSF pressure were measured by a blood pressure monitor (HP7835, Hewlett-Packard Company, Andover, Mass.) with disposable transducers (SCK7178, Viggo Spectramed Co. Ltd., Singapore). The zero level was adjusted at the operating table. Perfusion flow was calculated by the numbers derived from the pump rotation rate, which was calibrated with each pump circuit system after each procedure. The blood samples were drawn into heparinized syringes, placed immediately on ice, and analyzed at $37^{\circ} \mathrm{C}$ for $\mathrm{pH}$, oxygen tension, carbon dioxide tension, oxygen saturation, oxygen content, total carbon dioxide, and hemoglobin with the ABL-300 analyzer (Radiometer A/S, Copenhagen, Denmark). CBF was measured with the RBF-2 meter (Biomedical Science, Inc., Kanazawa, Japan) by the hydrogen clearance method. ${ }^{2,3}$ The $\mathrm{CBF}$ was calculated by subtracting blood flow at total circulatory arrest. 


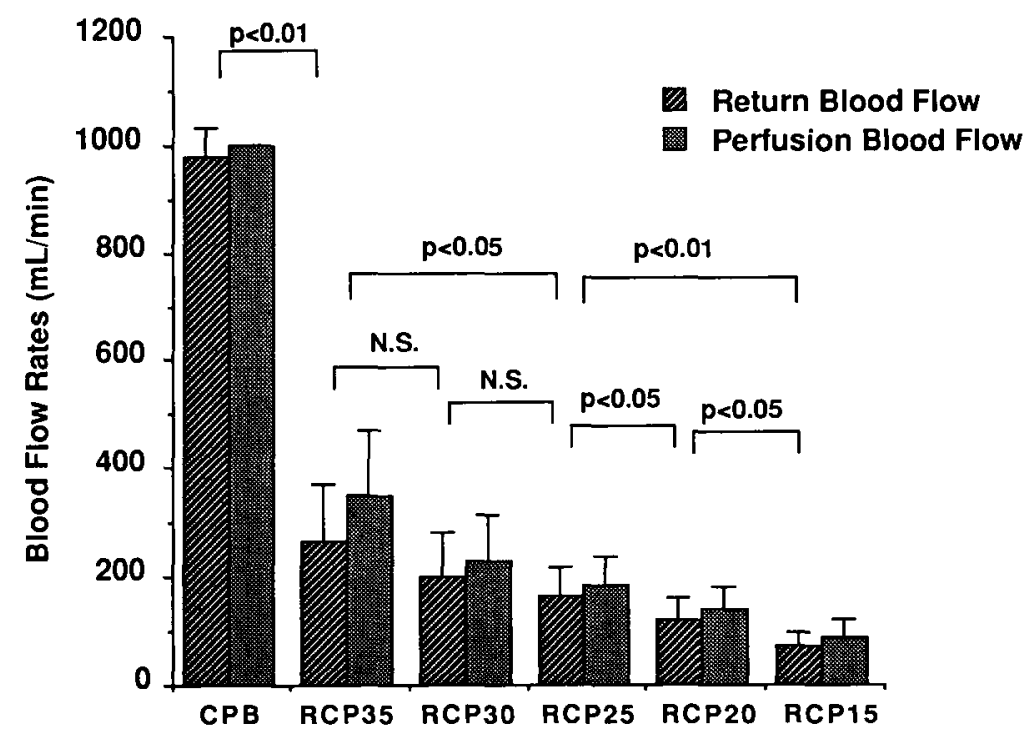

Fig. 2. Returned blood flow rates and perfusion blood flow rates during hypothermic $\left(20^{\circ} \mathrm{C}\right)$ cardiopulmonary bypass at $1000 \mathrm{ml} / \mathrm{min}(C P B)$ and hypothermic $\left(20^{\circ} \mathrm{C}\right)$ retrograde cerebral perfusion $(R C P)$ at an external jugular venous pressure of $15,20,25,30$, or $35 \mathrm{~mm} \mathrm{Hg.} \mathrm{N.S.,} \mathrm{Not} \mathrm{significant.}$

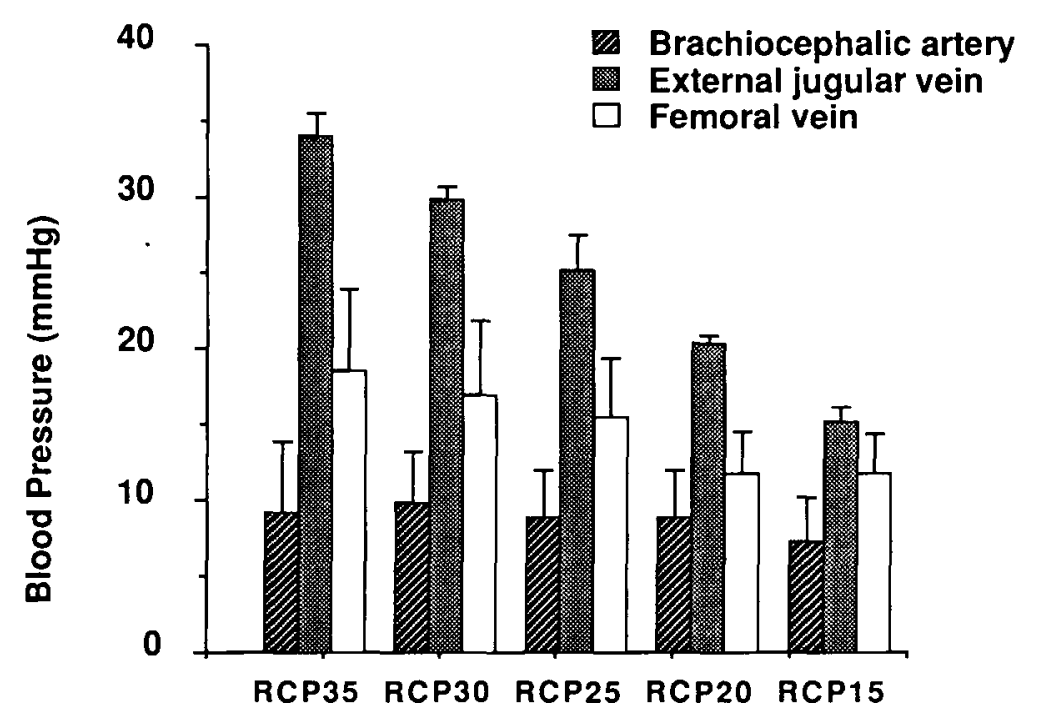

Fig. 3. Pressures in the brachiocephalic artery, external jugular vein, and femoral vein during hypothermic $\left(20^{\circ}\right.$ C) retrograde cerebral perfusion $(R C P)$ at an external jugular venous pressure of $15,20,25,30$, or $35 \mathrm{~mm} \mathrm{Hg}$.

Calculation. Total vascular resistance $(\mathrm{R})$ was calculated by the following formula:

$$
R=79920 \times(P i-P o) / Q\left(\text { dynes } \cdot \mathrm{sec} \cdot \mathrm{cm}^{-5}\right)
$$

where $\mathrm{Pi}$ is external jugular venous pressure, $\mathrm{Po}$ is brachiocephalic arterial pressure, and $Q$ is flow rate $(\mathrm{ml} / \mathrm{min})$ of blood returning via the aortic cannula during retrograde cerebral per- fusion and where $\mathrm{Pi}$ is brachiocephalic arterial pressure, $\mathrm{Po}$ is central venous pressure, and $Q$ is $1000 \mathrm{ml} / \mathrm{min}$ at control $\mathrm{CPB}$.

Oxygen consumption $\left(\mathrm{CMO}_{2}\right)$ was calculated from the equation:

$$
\mathrm{CMO}_{2}=\left(\mathrm{O}_{2} \mathrm{CTf}-\mathrm{O}_{2} \mathrm{CTr}\right) \times Q / 100(\mathrm{ml} / \mathrm{min})
$$

where $\mathrm{O}_{2} \mathrm{CTf}$ is the oxygen content of perfused blood, $\mathrm{O}_{2} \mathrm{CTr}$ 


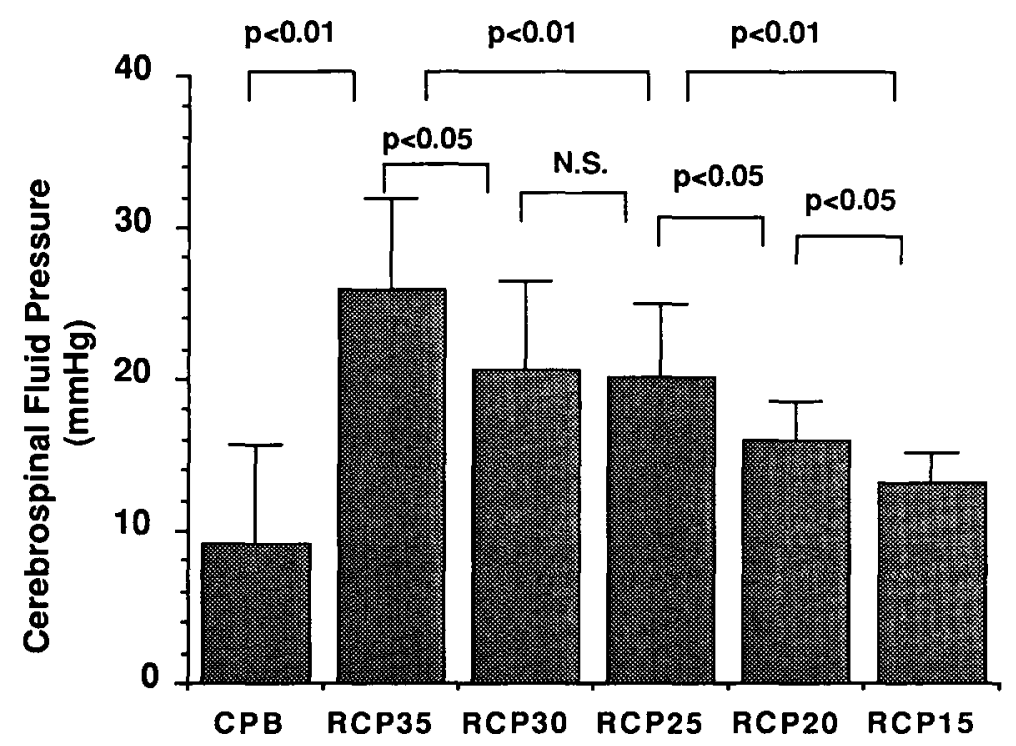

Fig. 4. Cerebrospinal fluid pressure during hypothermic $\left(20^{\circ} \mathrm{C}\right)$ cardiopulmonary bypass at $1000 \mathrm{ml} / \mathrm{min}(C P B)$ and hypothermic $\left(20^{\circ} \mathrm{C}\right)$ retrograde cerebral perfusion $(R C P)$ at an external jugular venous pressure of $15,20,25$, 30, or $35 \mathrm{~mm} \mathrm{Hg.} \mathrm{N.S.,} \mathrm{Not} \mathrm{significant.}$

is the oxygen content of returned blood, and $Q$ is the flow rate $(\mathrm{ml} / \mathrm{min})$ of blood returning via the aortic cannula during retrograde cerebral perfusion and $1000 \mathrm{ml} / \mathrm{min}$ at control CPB.

Exudation of carbon dioxide $\left(\mathrm{EXCO}_{2}\right)$ was calculated by the formula:

$$
\mathrm{ExCO}_{2}=\left(t \mathrm{CO}_{2} \mathrm{r}-t \mathrm{CO}_{2} \mathrm{f}\right) \times Q / 1000(\mathrm{mmol} / \mathrm{min})
$$

where $\mathrm{tCO}_{2} \mathrm{f}$ is the carbon dioxide content of perfused blood, $\mathrm{tCO}_{2} \mathrm{r}$ is the carbon dioxide content of returned blood, and $\mathrm{Q}$ is the flow rate $(\mathrm{ml} / \mathrm{min})$ of blood returning via the aortic cannula during retrograde cerebral perfusion and $1000 \mathrm{ml} / \mathrm{min}$ at control CPB.

Results are expressed as the mean \pm standard deviation and statistical significance was determined by means of the paired $t$ test.

\section{Results}

Blood flow. During hypothermic retrograde cerebral perfusion with the external jugular venous pressure at 25 $\mathrm{mm} \mathrm{Hg}$, flow rate of blood returning via the aorta was $164 \pm 53 \mathrm{ml} / \mathrm{min}$ and perfusion blood flow rate was $185 \pm 46 \mathrm{ml} / \mathrm{min}$, rates which were only one sixth of the control CPB. The aortic return blood flow rate was smaller than perfusion flow rate due to bleeding, blood retention into the liver or spleen, or making ascites retention, and it varied in proportion as did external jugular venous pressure (Fig. 2).

Blood pressure. During hypothermic retrograde cerebral perfusion with an external jugular venous pressure of $25 \mathrm{~mm} \mathrm{Hg}$, the femoral venous pressure was also increased $(14.4 \pm 3.6 \mathrm{~mm} \mathrm{Hg})$ and exceeded the bra-

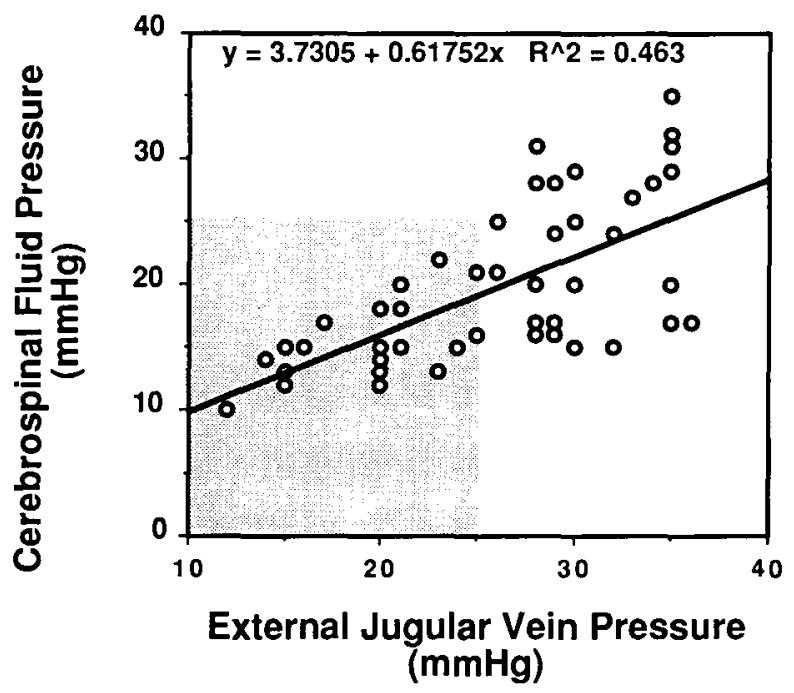

Fig. 5. Relation between cerebrospinal fluid pressure and external jugular venous pressure during hypothermic $\left(20^{\circ} \mathrm{C}\right)$ retrograde cerebral perfusion.

chiocephalic arterial pressure $(9.0 \pm 2.9 \mathrm{~mm} \mathrm{Hg})$. The difference between the external jugular venous pressure and the brachiocephalic arterial pressure increased as the external jugular venous pressure increased (Fig. 3).

CSF. The CSF pressure was lower than the external jugular venous pressure $(19.2 \pm 4.5 \mathrm{~mm} \mathrm{Hg}$ versus $24.8 \pm 2.4 \mathrm{~mm} \mathrm{Hg}$ ) but also increased in parallel with 


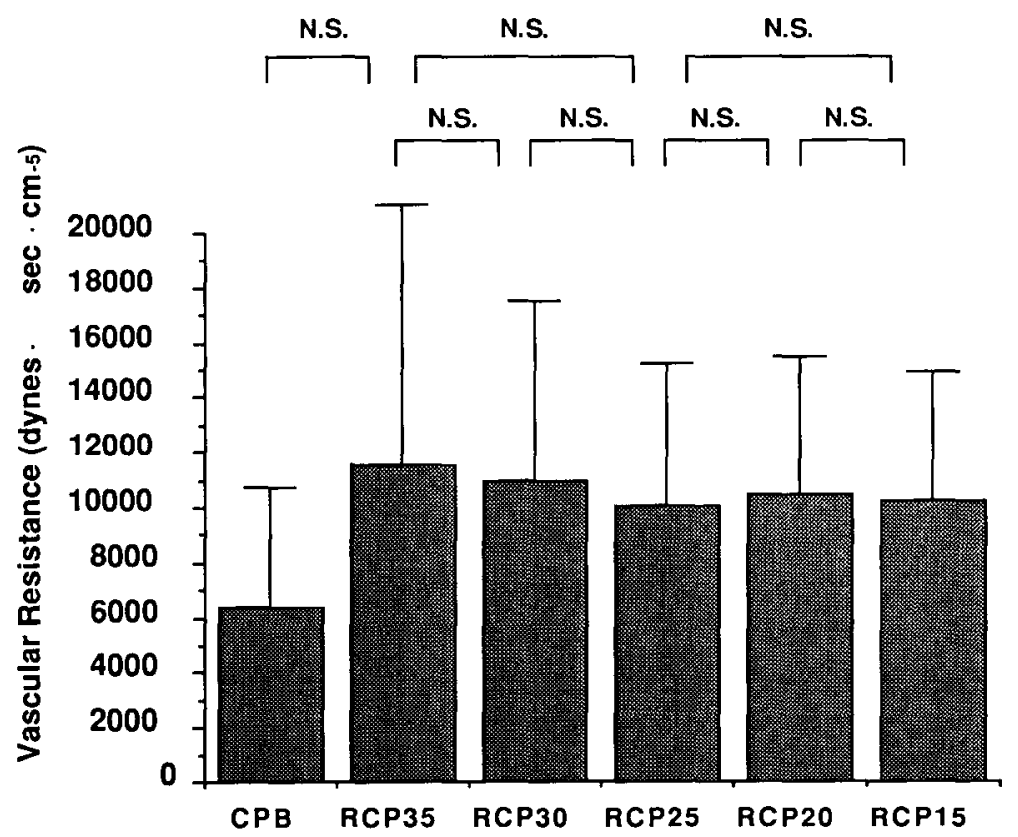

Fig. 6. Whole-body vascular resistance during hypothermic $\left(20^{\circ} \mathrm{C}\right)$ cardiopulmonary bypass at $1000 \mathrm{ml} / \mathrm{min}$ $(C P B)$ and hypothermic $\left(20^{\circ} \mathrm{C}\right)$ retrograde cerebral perfusion $(R C P)$ at an external jugular venous pressure of 15 , $20,25,30$, or $35 \mathrm{~mm} \mathrm{Hg}$. N.S., Not significant.

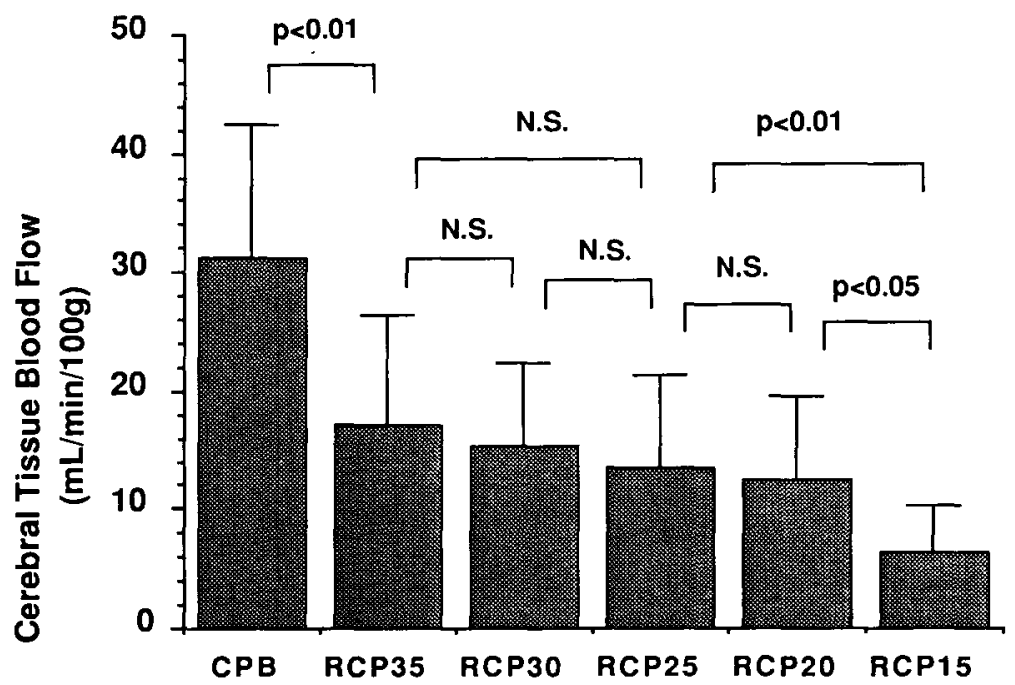

Fig. 7. Cerebral tissue blood flow of $100 \mathrm{gm}$ wet volume during hypothermic $\left(20^{\circ} \mathrm{C}\right)$ cardiopulmonary bypass at $1000 \mathrm{ml} / \mathrm{min}(C P B)$ or hypothermic $\left(20^{\circ} \mathrm{C}\right)$ retrograde cerebral perfusion $(R C P)$ at an external jugular venous pressure of $15,20,25,30$, or $35 \mathrm{~mm} \mathrm{Hg}$. N.S., Not significant.

any increase in the external jugular venous pressure (Fig. 4). The CSF pressure remained lower than $25 \mathrm{~mm} \mathrm{Hg}$ so long as the external jugular venous pressure was lower than $25 \mathrm{~mm} \mathrm{Hg}$ (Fig. 5).

Total vascular resistance. Total vascular resistance did not change significantly from CPB to retrograde cerebral perfusion and did not change significantly under various retrograde cerebral perfusion conditions (Fig. 6).

CBF. Hypothermic retrograde cerebral perfusion with an external jugular venous pressure of $25 \mathrm{~mm} \mathrm{Hg}$ provid- 


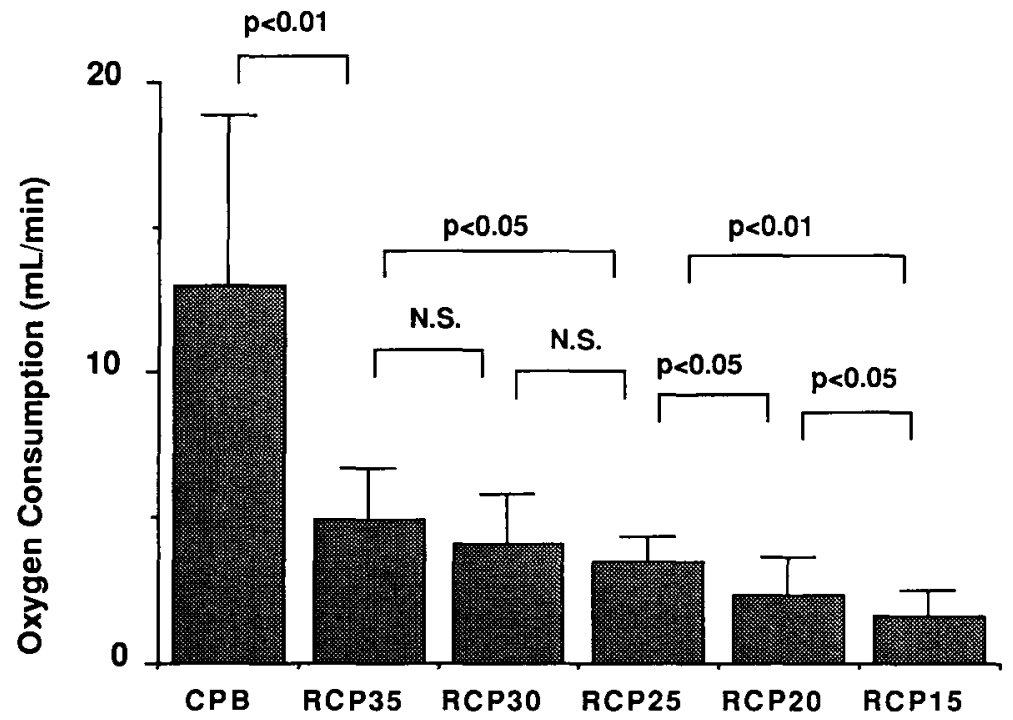

Fig. 8. Whole-body oxygen consumption calculated during hypothermic $\left(20^{\circ} \mathrm{C}\right)$ cardiopulmonary bypass at 1000 $\mathrm{ml} / \mathrm{min}(C P B)$ and hypothermic $\left(20^{\circ} \mathrm{C}\right)$ retrograde cerebral perfusion $(R C P)$ at an external jugular venous pressure of $15,20,25,30$, or $35 \mathrm{~mm} \mathrm{Hg.} \mathrm{N.S.,} \mathrm{Not} \mathrm{significant.}$

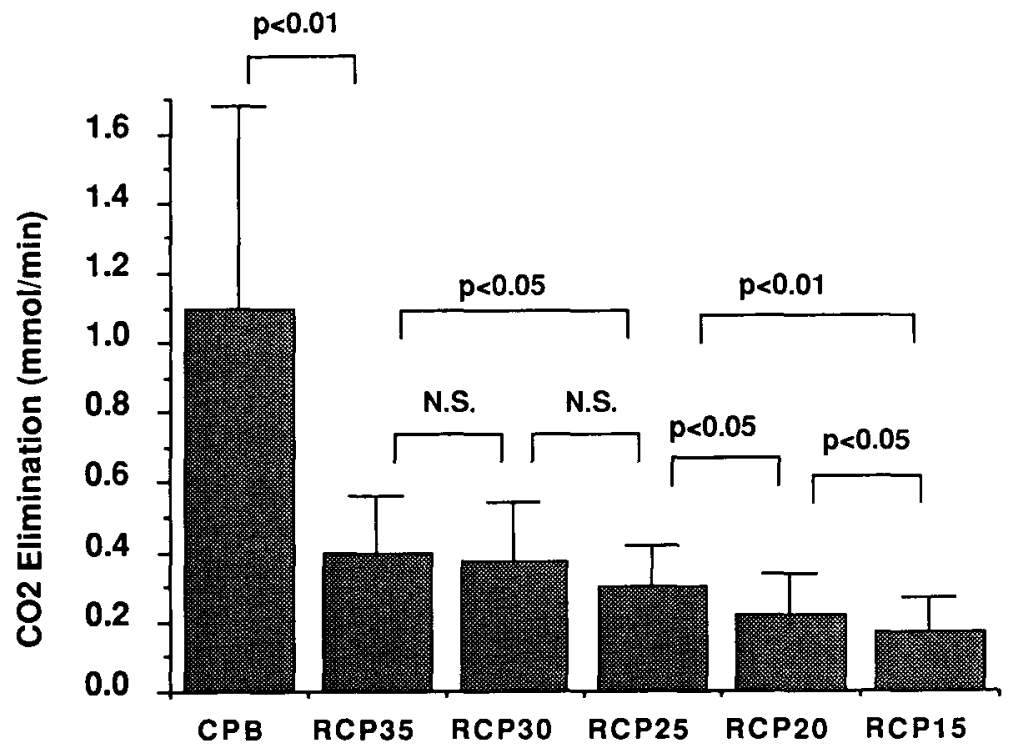

Fig. 9. Carbon dioxide elimination during hypothermic $\left(20^{\circ} \mathrm{C}\right)$ cardiopulmonary bypass at $1000 \mathrm{ml} / \mathrm{min}(C P B)$ and hypothermic $\left(20^{\circ} \mathrm{C}\right)$ retrograde cerebral perfusion $(R C P)$ at an external jugular venous pressure of $15,20,25$, 30 , or $35 \mathrm{~mm} \mathrm{Hg.} \mathrm{N.S.,} \mathrm{Not} \mathrm{significant.}$

ed about half the CBF provided by hypothermic controlled CPB $(13.7 \pm 7.9$ versus $32.7 \pm 8.5 \mathrm{ml} / \mathrm{min}$ per $100 \mathrm{gm})$. CBF decreased significantly as the external jugular venous pressure decreased from 25 to $15 \mathrm{~mm} \mathrm{Hg}$; however, it did not increase significantly as the external jugular venous pressure increased from 25 to $35 \mathrm{~mm} \mathrm{Hg}$ (Fig 7).

Oxygen consumption. During hypothermic retro- 
grade cerebral perfusion with an external jugular venous pressure of $25 \mathrm{~mm} \mathrm{Hg}$, the oxygen consumption was one quarter of that during hypothermic control $\mathrm{CPB}$ ( $3.4 \pm 0.7$ versus $12.7 \pm 5.6 \mathrm{ml} / \mathrm{min}$ ). The oxygen consumption varied in proportion to the external jugular venous pressure. It decreased significantly in decrements of $5 \mathrm{~mm} \mathrm{Hg}$ from an external jugular venous pressure of $25 \mathrm{~mm} \mathrm{Hg}$. However, it increased significantly only in increments of $10 \mathrm{~mm} \mathrm{Hg}$ when external jugular venous pressure was higher than $25 \mathrm{~mm} \mathrm{Hg}$ (Fig. 8).

Elimination of carbon dioxide. The elimination of carbon dioxide during hypothermic retrograde cerebral perfusion with an external jugular venous pressure of 25 $\mathrm{mm} \mathrm{Hg}$ was one quarter of that during hypothermic control CPB. The elimination of carbon dioxide varied in proportion to the change in the external jugular venous pressure. It increased significantly in increments of $5 \mathrm{~mm}$ $\mathrm{Hg}$ when the external jugular venous pressure was lower than $25 \mathrm{~mm} \mathrm{Hg}$; however, significant increase was observed only in increments of $10 \mathrm{~mm} \mathrm{Hg}$ when the external jugular venous pressure exceeded $25 \mathrm{~mm} \mathrm{Hg}$ (Fig. 9).

\section{Discussion}

Protection of the brain is of great importance when the cerebral circulation is interrupted during operations on the aortic arch. Deep hypothermic circulatory arrest or isolated cerebral perfusion has been commonly used to protect the brain. ${ }^{4-8}$ However, neither technique is entirely satisfactory. Retrograde perfusion through an SVC cannula is a new techniques used to protect the brain during circulatory arrest. It was first used to manage massive air embolism during $\mathrm{CPB} .^{9}$ As a technique for protecting the brain, retrograde cerebral perfusion was first reported by Lemole and Ueda. ${ }^{10,11}$ We have been using retrograde cerebral perfusion during operations on the aortic arch since January 1990.

The patient is cooled to a nasopharyngeal core temperature of $20^{\circ} \mathrm{C}$ during normograde CPB. Then retrograde cerebral perfusion is performed by infusing via the SVC cannula and draining via the aortotomy while the inferior vena cava (IVC) is clamped and while SVC pressure is being monitored. We maintain a nasopharyngeal core temperature around $20^{\circ} \mathrm{C}$ with intermittent cooling of infused solution and also maintain SVC pressure around $30 \mathrm{~mm} \mathrm{Hg}$ while controlling inflow rate. However, the optimum pressure for retrograde cerebral perfusion is not clear. We $\mathrm{e}^{1}$ have already reported that retrograde cerebral perfusion can provide blood and oxygen to both the brain and the body and that this perfusion may reduce ischemic damage to the brain. In this study, we sought to determine the optimum parameters for retrograde cerebral perfusion.

We found that CSF pressure varied in parallel with external jugular venous pressure. CBF, however, did not increase significantly as external jugular venous pressure increased over $25 \mathrm{~mm} \mathrm{Hg}$. Venous pressure, arterial pressure, intracranial pressure, and cerebral vascular resistance are principal factors to reflect $\mathrm{CBF}$ during retrograde cerebral perfusion. As venous pressure, a driving pressure during retrograde cerebral perfusion, increases, cerebral tissue blood flow should be increased. However, high venous pressure is associated with high intracranial pressure, which restricts CBF. Therefore, CBF does not increase once the external jugular venous pressure exceeds $25 \mathrm{~mm} \mathrm{Hg}$. According to the Monro-Kellie doctrine, the amount of the brain, CSF, and intracranial blood does not change at any time because of a certain volume in the intracranial space, and CSF pressure is almost equal to intracranial venous pressure at any time. Therefore, as venous pressure increases, CSF pressure increases simultaneously and high intracranial pressure compresses the vascular vessels and decreases CBF.

CSF pressure represents the pressure of the intercellular space in the brain. Therefore, high venous pressure is associated with high intercellular fluid pressure, which may cause brain edema. Any CSF pressure that exceeds $17.5 \mathrm{~mm} \mathrm{Hg}$ or $200 \mathrm{~cm} \mathrm{H}_{2} \mathrm{O}$ may be associated with brain edema.

As external jugular venous pressure increased, so did oxygen consumption. However, CBF did not increase once venous pressure exceeded $25 \mathrm{~mm} \mathrm{Hg}$. Increase of oxygen consumption, when external jugular venous pressure exceeded $25 \mathrm{~mm} \mathrm{Hg}$, may reflect an increase of blood flow except to the brain. It is important, therefore, that the optimum venous pressure for retrograde cerebral perfusion, the lowest pressure that provides effective $\mathrm{CBF}$ and the highest pressure under which brain edema does not result, be determined. We believe that a venous pressure of $25 \mathrm{~mm} \mathrm{Hg}$ can be used safely with the maximum CBF.

During retrograde cerebral perfusion, a high SVC system pressure is associated with a high IVC system pressure, and both are higher than that in the arterial system. This indicates that the SVC communicates well with the IVC system and that blood infused through the SVC may also perfuse visceral organs. This may be an added advantage to the use of retrograde cerebral perfusion. However, flow rate of blood returning via the aortic cannula was smaller than perfusion flow rate despite blood loss resulting from bleeding. This fact may indicate that blood is retained in the body, causing hepatic and splenic distention. Portal venous pressure was almost equal to 
femoral venous pressure and also increased in parallel with SVC system pressure (unpublished data). It causes ascitis, which results in circulatory volume loss.

Inasmuch as the aortic cannula is directed by gravity to the cardiotomy reservoir during retrograde cerebral perfusion, aortic root pressure presumably would be zero. However, average brachiocephalic arterial pressure was $9 \mathrm{~mm} \mathrm{Hg}$ at an external jugular venous pressure of $25 \mathrm{~mm}$ $\mathrm{Hg}$. According to the Monro-Kellie doctrine, as intracranial pressure increases, pressure in any intracranial vessels increases. This may be one of the reason that brachiocephalic arterial pressure was high.

In this study $\mathrm{CBF}$ was measured by the hydrogen clearance technique, a standard technique that has been confirmed by many studies. We also measured CBF by the colored microsphere method, which consists of $50 \mu \mathrm{m}$ of microspheres, in another 12 dogs (unpublished data.). Tissue blood flow of the cerebral cortex in the midparietal lobe, which was measured by the colored microsphere method, was $36.2 \pm 16.9 \mathrm{ml} / \mathrm{min}$ per $100 \mathrm{gm}$ at hypothermic control CPB and $11.0 \pm 10.5 \mathrm{ml} / \mathrm{min}$ per 100 gm at hypothermic retrograde cerebral perfusion with an external jugular venous pressure of $25 \mathrm{~mm} \mathrm{Hg}$. These values were almost same as those measured by the hydrogen clearance method.

Whole-body oxygen consumption decreases greatly as body temperature decreases, ${ }^{12-15}$ and deep hypothermia. can minimize ischemic damage to the brain. A safe duration of circulatory arrest during deep hypothermia was reported to be 45 to 60 minutes. ${ }^{16-19}$ Retrograde cerebral perfusion at an external jugular venous pressure of $25 \mathrm{~mm}$ $\mathrm{Hg}$ can supply one quarter of the oxygen provided by $\mathrm{CPB}$ at $1000 \mathrm{ml} / \mathrm{min}$ and may also minimize ischemic damage to the brain. Deep hypothermic retrograde cerebral perfusion, therefore, should extend the period of time during which the cerebral circulation may be safely interrupted. Retrograde cerebral perfusion can also be used to lower brain temperature. The brain temperature was measured in six dogs in this study. During retrograde cerebral perfusion the brain can be maintained at a certain temperature, which is almost the same as the nasopharyngeal core temperature, with intermittent cooling of the infusion solution. This may be yet another advantage for retrograde cerebral perfusion.

In this study, blood was perfused directly into the temporal sinus bilaterally via the internal maxillary veins to avoid venous valves that would interfere with retrograde perfusion. ${ }^{20,21}$ Blood perfusion via each internal maxillary vein was observed directly after each procedure to confirm no interference by venous valves. The dog, which has a small internal jugular vein with many venous valves, is not a good model for retrograde cerebral perfusion. ${ }^{22}$ Nevertheless, this experimental study may suggest some parameters for using retrograde cerebral perfusion in human beings.

Retrograde cerebral perfusion can be performed without clamping or cannulating the cervical arteries. It should reduce any chance of cerebral thrombosis and also provide a better operative field. Retrograde cerebral perfusion can extend the duration of safe cerebral circulatory arrest; however, there is a limit to this duration of circulatory arrest and, furthermore, high venous pressures may cause brain edema.

This study was prepared in consultation with a statistician, Nobuyuki Hamajima, MD.

\section{REFERENCES}

1. Usui A, Hotta T, Hiroura M, et al. Retrograde cerebral perfusion through a superior vena caval cannula protects the brain. Ann Thorac Surg 1992;53:47-53.

2. Doyle TF, Martins AN, Kobrine AI. Estimating total cerebral blood flow from the initial slope of hydrogen washout. Stroke 1975;6:149-52.

3. Pasztor E, Symon L, Dorsch NWC, Branston NM. The hydrogen clearance method in assessment of blood flow in cortex, white matter and deep nuclei of baboons. Stroke 1973;4:556-67.

4. Ott DA, Frazier OH, Cooley DA. Resection of aortic arch using deep hypothermia and temporary circulation arrest. Circulation 1978;58(Suppl):I227-31.

5. Cooley DA, Ott DA, Frazier OH, Walker WE. Surgical treatment of aneurysms of the transverse aortic arch: experience with 25 patients using hypothermic techniques. Ann Thorac Surg 1981;32:260-72.

6. Ergin MA, Griepp R B. Progress in treatment of aneurysms of the aortic arch. J THORAC CARdIOvasC SuRG 1978; 76:385-9.

7. Livesay JJ, Cooley DA, Duncan JM, Ott DA, Walker WE, Reul GJ. Open aortic anastomosis: improved results in the treatment of aneurysms of the aortic arch. Circulation 1982;66(Suppl):I122-7.

8. Crawford SE, Saleh SA. Transverse aortic arch aneurysm: improved results of treatment employing new modifications of aortic reconstruction and hypothermic cerebral circulatory arrest. Ann Surg 1981;194:180-8.

9. Mills NL, Ochsner JL. Massive air embolism during cardiopulmonary bypass: causes, prevention, and management. J ThORac Cardiovasc Surg 1980;80:708-17.

10. Lemole GM, Strong MD, Spagna PM, Karmilowicz NP. Improved results for dissecting aneurysms: intraluminal sutureless prosthesis. J THORAC CARDIOvaSC SuRG 1982; 83:249-55.

11. Ueda Y, Miki S, Kusuhara K, Okita Y, Tahara T, Yamanaka K.Surgical treatment of aneurysm of dissection 
involving the ascending aorta and aortic arch, utilizing circulatory arrest and retrograde cerebral perfusion. J Cardiovasc Surg 1990;31:553-8.

12. Fox LS, Blackstone EH, Kirklin JW, Bishop SP, Bergdarl LA, Bradley EL. Relationship of brain blood flow and oxygen consumption to perfusion flow rate during profoundly hypothermic cardiopulmonary bypass: an experimental study. J Thorac CARdiovasc Surg 1984;87:658-64.

13. Bigelow WG, Lindsay WK, Harrison RC, Gordon RA, Greenwood WF. Oxygen transport and utilization in dogs at low temperature. Am J Physiol 1950;160:125-37.

14. Harris EA, Seelye EE, Squire AW. Oxygen consumption during cardiopulmonary bypass with moderate hypothermia in man. Br J Anaesth 1971;43:1113-20.

15. Kent G, Peirce EC II. Oxygen consumption during cardiopulmonary bypass in the uniformly cooled dog. J Appl Physiol 1974;37:917-22.

16. Kramer RS, Sanders AP, Lesage AM, Woodhall B, Sealy WC. The effect of profound hypothermia on preservation of cerebral ATP content during circulatory arrest. J THORaC Cardiovasc Surg 1968;56:699-709.
17. Fisk GC, Wright JS, Hicks RG, et al. The influence of duration of circulatory arrest at $20^{\circ} \mathrm{C}$ on cerebral changes. Anaesth Intensive Care 1976;4:126-34.

18. Treasure T, Naftel DC, Conger KA, Garcia JH, Kirklin JW, Blackstone EH. The effect of hypothermia and circulatory arrest. J THORAC CARDIOVASC SURG 1983;86:76170.

19. O'Conner JV, Wilding T, Farmer P, Sher J, Ergin MA, Griepp RB. The protective effect of profound hypothermia on the canine central nervous system during one hour of circulatory arrest. Ann Thorac Surg 1986;41:255-9.

20. Midy PD, Lehuec JC, Dumont D, Chauveaux D, Cabanie $\mathrm{H}$, Laude $\mathrm{M}$. Etude anatomique et histologique des valves des veins jugulaires internes. Bull Assoc Anat 1988;72: 21-9.

21. Adachi B. Das Venensystem der Japaner. In: Adachi B, ed. Anatomie der Japner. Tokyo: Kenkyusha, 1933:78-82.

22. Miller MM. The venous system. In: Miller MM, ed. Anatomy of the dog. Philadelphia: WB Saunders, 1964:389-435. 